\title{
Anticipation of Penalty Kick to a Goal Keeper
}

\author{
Johansyah Lubis ${ }^{1}$ \\ ${ }^{1}$ Faculty of Sports Science, Universitas Negeri Jakarta, Indonesia \\ Correspondence: Johansyah Lubis, Faculty of Sports Science, Universitas Negeri Jakarta, Kampus B, Jl. Pemuda \\ 10, Rawamangun, Jakarta 13220, Indonesia. E-mail: jlubis@unj.ac.id
}

Received: January 16, 2014 Accepted: February 20, 2014 Online Published: February 28, 2014

doi:10.5539/ass.v10n5p55

URL: http://dx.doi.org/10.5539/ass.v10n5p55

\begin{abstract}
The objective of this research is to determine the correlation between speed of reaction $\left(\mathrm{X}_{1}\right)$, agility $\left(\mathrm{X}_{2}\right)$ and confidence $\left(\mathrm{X}_{3}\right)$ with anticipation of the penalty kick $(\mathrm{Y})$. This research was conducted with a sample of 10 respondents selected using purposive sampling. The results of this research are as follows. First, there is a positive correlation between speed of reaction toward the anticipation of the penalty kick. The linear regression is express through $\hat{Y}=-6.74+43.82 X_{1}$. The correlation coefficient 0.773 . It means the speed of reaction toward the anticipation the penalty kick is $60 \%$. Second, there is a positive correlation between agility toward the anticipation of the penalty kick. The linear regression is expressed through $\hat{\mathrm{Y}}=-10.42+0.86 \mathrm{X}_{2}$. The correlation coefficient is 0.784 . It means the agility toward the anticipation of the penalty kick is $59 \%$. Third, there is a positive correlation between confidence toward the anticipation of the penalty kick. The linear regression is expressed through $\hat{Y}=27.73+0.40 \mathrm{X}_{3}$. The correlation coefficient is 0.784 . It means the confidence toward the anticipation of the penalty kick is $61 \%$. Fourth, there is a positive correlation between speed of reaction, agility and confidence with the anticipation of the penalty kick. The linear regression is expressed through $\hat{\mathrm{Y}}=-24.995$ $+430.37 \mathrm{X}_{1}+0.016 \mathrm{X}_{2}+0.198 \mathrm{X}_{3}$. The correlation coefficient correlation is 0.9105 . It's mean the speed of reaction, agility and confidence with anticipation the penalty kick is $91 \%$.
\end{abstract}

Keywords: penalty kick, goal keeper

\section{Introduction}

A goalkeeper's task is to secure his net by catching, hitting or even chasing off the ball with any part of his body so that the ball does not go over the line and into his net. A goalkeeper in soccer is a player who is allowed to kick, catch, or hit the ball to prevent it from going into the net within the allowed area for him (http://id.wikipedia.org/wiki/Penjaga_gawang).

A goalkeeper, in order to anticipate a penalty kick, must have good reaction speed and agility. An opponent and a ball are stimulus that can be seen by the eyes of a goalkeeper, so a goalkeeper must quickly make a decision in giving orders to the muscle to perform movements quickly to save the ball. (Saleh, 1979: 8-9)

A penalty kick in soccer is a difficult and dangerous situation for a goalkeeper. In order to successfully deal with such situation, a goalkeeper should be ready mentally and confident in order to keep his goal safe.

A goalkeeper must learn to read and predict where the ball is about to be kicked to from the tendency of the kick's direction. In order to read the ball properly, a goalkeeper must watch the kicker's eyes and overall actions, watch the approach, keep a close eye on the planted foot, hips and head, and do not react too soon (jbgoalkeeping.com).

According to Johnson and Nelson (1979), the terms reaction time and speed of reaction are used alternately to state one's ability in providing kinetic response to the stimulus presented unexpectedly, the reaction time is intended more to explain in relation with time, whereas the speed of reaction is intended more to the direction of the movement. The speed of reaction involves the processes of the central nervous system in developing response sharpness. First, a sensory organ is driven by some stimulus; awaking a sensory organ and is then transfered to nerve impulses and carried to the brain. A similar opinion said that the speed of reaction is the period of the emergence of the stimulus until the beginning of the response. So the speed of reaction is the time required to perform the inception of the response or the interval between the stimulus to the response. (Oxendine, 1984) 
Movement time starts when the body movement is recognized (not when the stimulus is identified) and ends when the body movement stops.

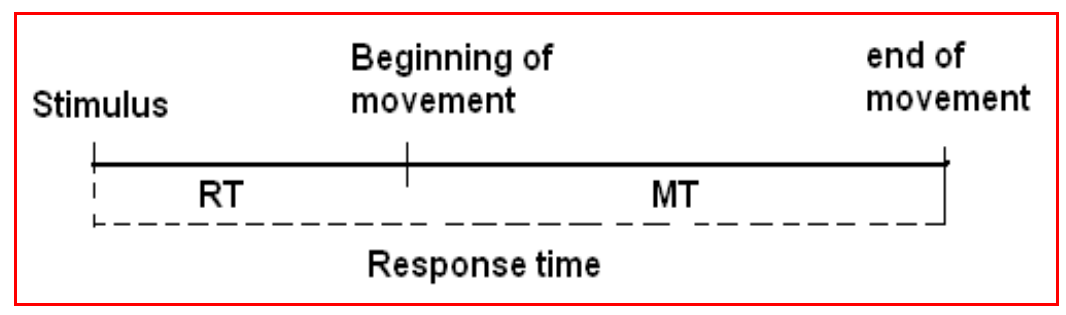

Figure 1. Reaction time (RT), movement time (MT) and response time

Source: Goerge H. Sage, Introduction to Motor Behaviour: A Neuropsyscological Approach

Agility is a combination of speed and coordination (Bompa, 1999) Agility is a person's ability to change the body position to a particular direction. Someone who is able to change to a different position at high speeds with precise coordination means his agility is very good.

Self-confidence is a goalkeeper's beliefs and attitude towards his own ability. Self confidence can be positive or negative that is formed and learned through the learning process..

According to Peter Lauser in his book entitled Personality Tests translated by DH Gulobahwa: some psychological aspects that can be used to help a personal establishment, or improve one's personality is self-confidence. (Sujanto, 1982). According to Singer: to face athletes who don't believe in themselves (lack of confidence), a coach can help athletes finds his own identity (sense of identity), i.e to better understand the circumstances that has occurred to him. (Setyobroto, 2001)

According to Vealey and Knight in his book, based on the model of sport, self-confidence is identified as three components or dimensions in sport, namely:

1) Physical Skills and Training

Self-confidence is closely related to athlete's perception regarding to their physical abilities.

2) Cognitive Efficiency

Cognitive efficiency is an athlete's level of confidence or belief that he is able to focus himself, maintain concentration and make decisions in order to demonstrate successful performance.

3) Tenacity

Tenacity is an athlete's level of confidence or belief that he is able to focus again after his failure. (Vealey, R.S.)

\section{Methodology}

The method used for this study is a survey method. Meanwhile, the statistical technique used is correlation analysis, i.e linking variables between the independent variables with the dependent variable, so that in this study there is no control over the treatment. The independent variables consist of three variables: the speed of reaction $\left(\mathrm{X}_{1}\right)$, agility $\left(\mathrm{X}_{2}\right)$ and self-confidence $\left(\mathrm{X}_{3}\right)$, while the dependent variable is anticipation of the penalty kick $(\mathrm{Y})$.

The design study can be seen as follows: 


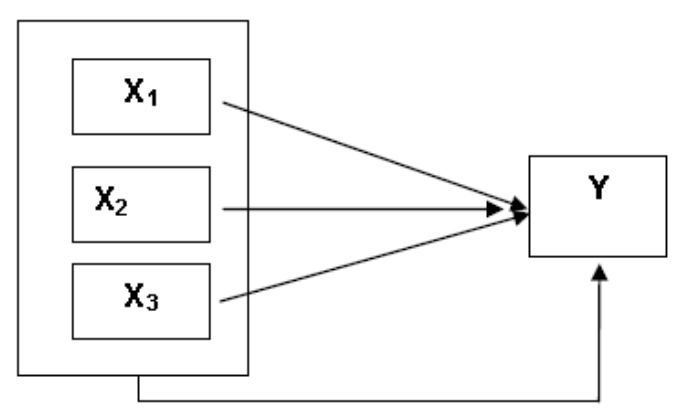

Figure 2. The research design

Description:

$\mathrm{X}_{1}=$ The speed of Reaction

$\mathrm{X}_{2}=$ Agility

$\mathrm{X}_{3}=$ Self-confidence

$\mathrm{Y}=$ The Anticipation of the Penalty Kick

The pilot test for the instrument was conducted in the school's soccer field.The study was conducted in two phases: the first phase is the pilot test and the second phase of the study was collecting the actual data for analysis. The target population in this study were all goalkeepers of soccer club's Universitas Neger Jakarta.

Methods use to collect data for the study were anticipation of penalty kick which is the goalkeeper's ability to read the direction of the ball and moving towards the ball quickly has a reliability of 0.872 and valid through face validity. The speed of reaction measurements was performed with visual stimulus by using whole-body reaction test for eye-hands and eye-foot has a reliability of 0.811 . Agility is the ability to change direction in reaction to a stimulus and in this case the stimulus is in the form of a ball kicked from various directions at varying speed has a reliability of 0.8 . Self-confidence is a confidence test with the following constructs a. Physical skills and Training (goalkeeping techniques. attends training without failure) b. Cognitive Efficiency (concentration during training, ability to make decisions quickly) c. Tenacity (concentration during the game, never gives up, 3. trying or playing with maximal effort). The instrument was pilot tested with a reliability value of 0.978 .

\section{Results}

Data analysis presented in this article includes four variables, i.e. anticipation of the penalty kick (Y), speed of reaction $\left(\mathrm{X}_{1}\right)$, agility $\left(\mathrm{X}_{2}\right)$ and self-confidence $\left(\mathrm{X}_{3}\right)$. The data collected is presented in the form of descriptive statistics shown as follows.

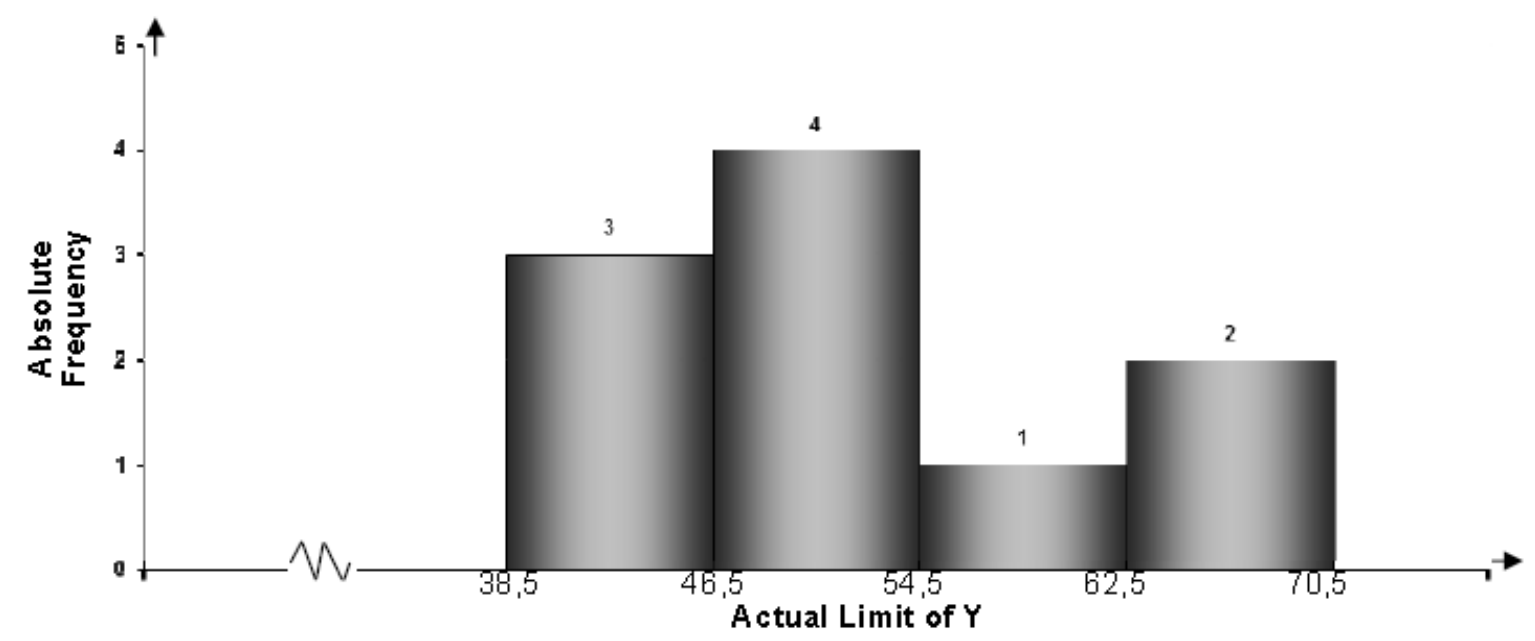

Figure 3. Histogram for anticipation of penalty kick 


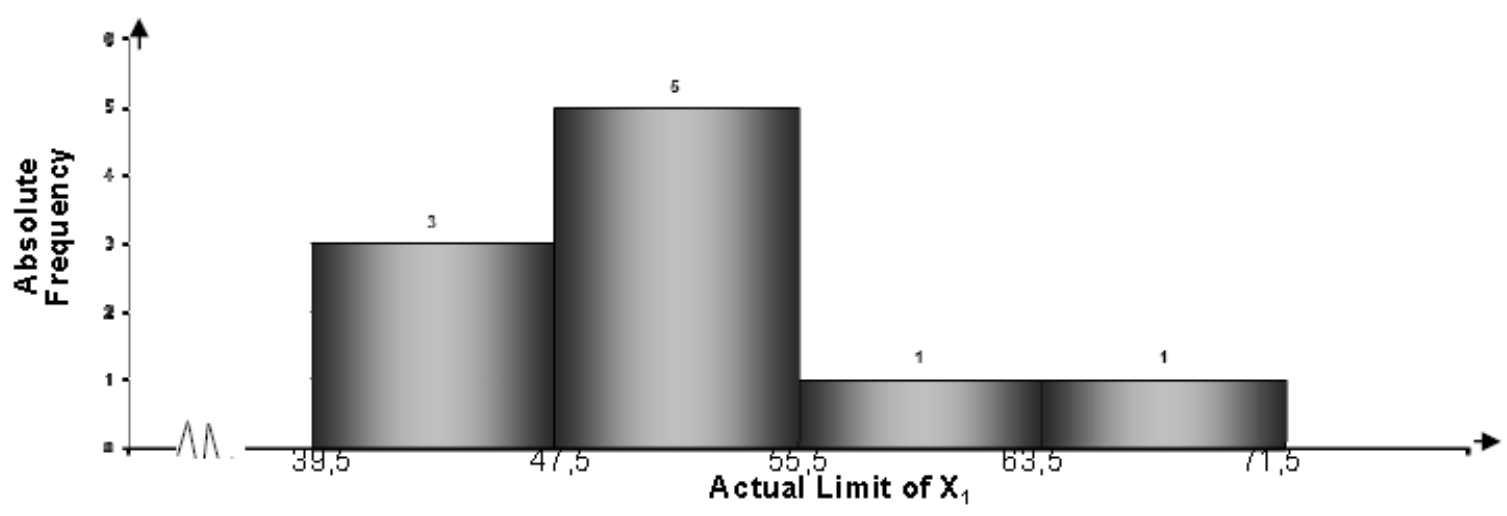

Figure 4. Histogram for the speed of reaction

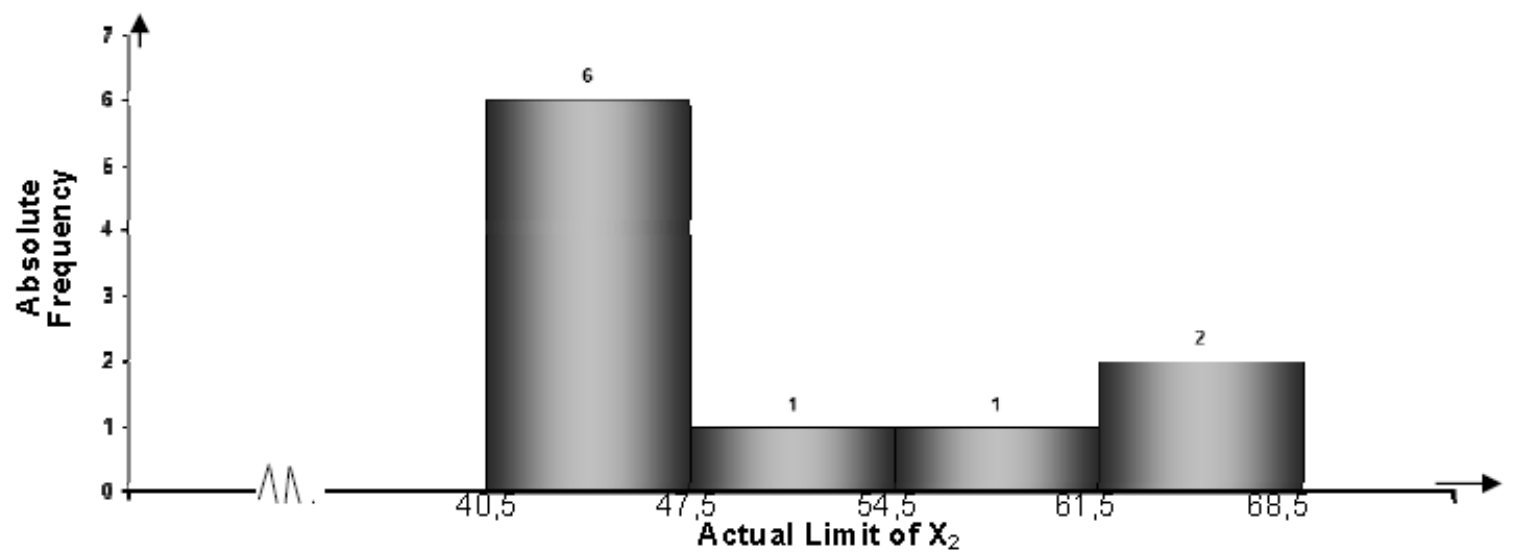

Figure 5. Histogram for agility

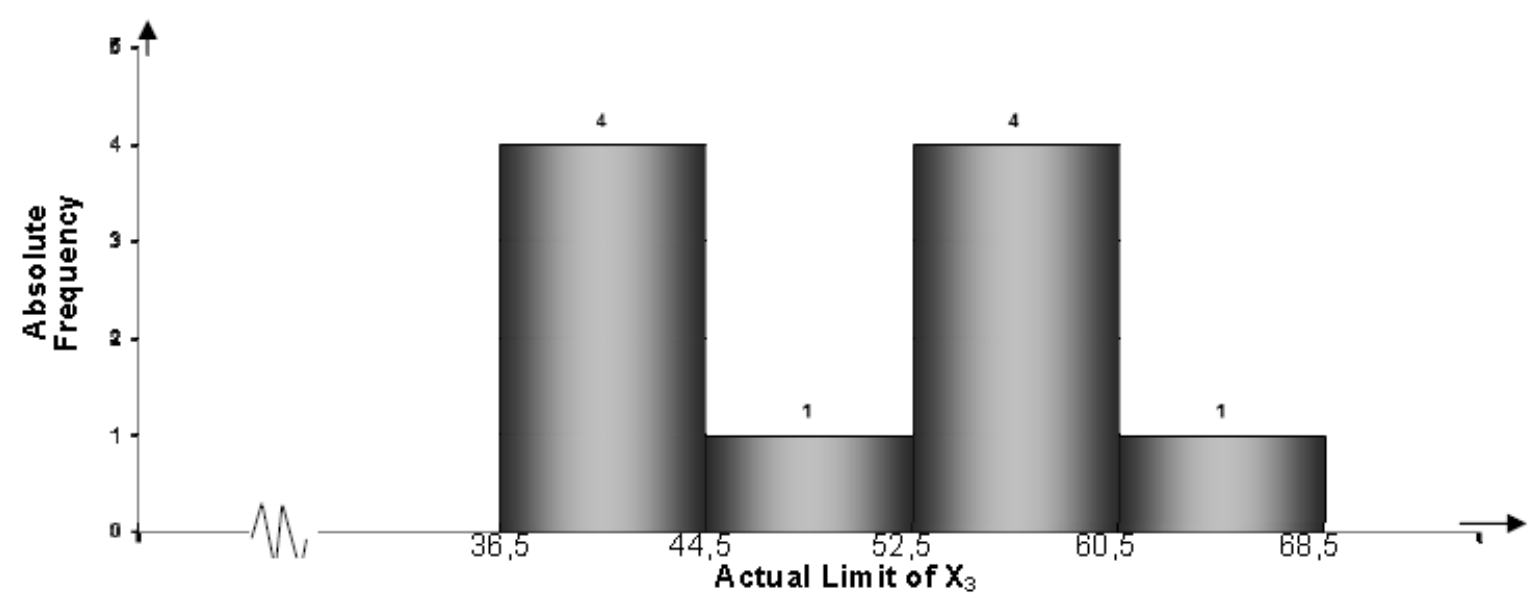

Figure 6. Histogram for self-confidence

\subsection{Analysis for Inferential Statistics}

\subsubsection{Normality Test}

Based on the normality test conducted, it can be concluded that the null hypothesis $\left(\mathrm{H}_{0}\right)$ that states samples were 
not normally distributed can be rejected, in other words, all of the samples are selected from normally distributed population. Normality test calculation results are shown in Table 1.

Table 1. Normality test results of estimation error

\begin{tabular}{|c|c|c|c|c|c|c|}
\hline \multirow{2}{*}{ Number } & \multirow{2}{*}{ Estimation Error Regresion } & \multirow{2}{*}{$\mathrm{N}$} & \multirow[b]{2}{*}{$\mathrm{L}_{\text {calculated }}$} & \multicolumn{2}{|c|}{$\mathrm{L}_{\text {table }}$} & \multirow{2}{*}{ Description } \\
\hline & & & & $\alpha=5 \%$ & $\alpha=1 \%$ & \\
\hline 1 & Y over $\mathrm{X}_{1}$ & 10 & 0.1327 & 0.258 & 0,294 & Normal \\
\hline 2 & $\mathrm{Y}$ over $\mathrm{X}_{2}$ & 10 & 0.1236 & 0.258 & 0,294 & Normal \\
\hline 3 & Y over $\mathrm{X}_{3}$ & 10 & 0.1093 & 0.258 & 0,294 & Normal \\
\hline
\end{tabular}

\subsubsection{Homogeneity Test}

Based on analysis of data, it can be concluded that the sample is homogeneous as shown in Table 2 .

Table 2. Homogeneity test results

\begin{tabular}{ccccccl}
\hline \multirow{2}{*}{ Number } & \multirow{2}{*}{ Variance } & \multirow{2}{*}{$\mathrm{dk}_{\text {calculated }}$} & $\alpha=5 \%$ & $\alpha=1 \%$ & \multirow{2}{*}{ Description } \\
& & & & & \\
\hline 1 & Y over $\mathrm{X}_{1}$ & 5 & 0,056 & 11,070 & 15,086 & Homogeneous \\
2 & ${\text { Y over } \mathrm{X}_{2}}_{3}$ & 7 & 0,597 & 14,067 & 18,475 & Homogeneous \\
3 & ${\text { Y over } \mathrm{X}_{3}}^{2}$ & 8 & 0,007 & 15,507 & 20,090 & Homogeneous \\
\hline
\end{tabular}

\subsubsection{Hypothesis Testing}

The first analysis showed that the coefficient of the regression direction of $b$ of 0.93 and a constant of 3.13 . Thus, it was obtained that the relationship between the Speed of Reaction $\left(\mathrm{X}_{1}\right)$ with the Anticipation of the Penalty Kick $(\mathrm{Y})$ which is expressed by the regression equation of $\hat{Y}=3.13+0.93 \mathrm{X}_{1}$. This regression equation implies that for every one unit increase in the speed of reaction score there will be an increase of anticipation of penalty kick score by 0.93 units at a constant of 3.13 as presented in Figure 7.

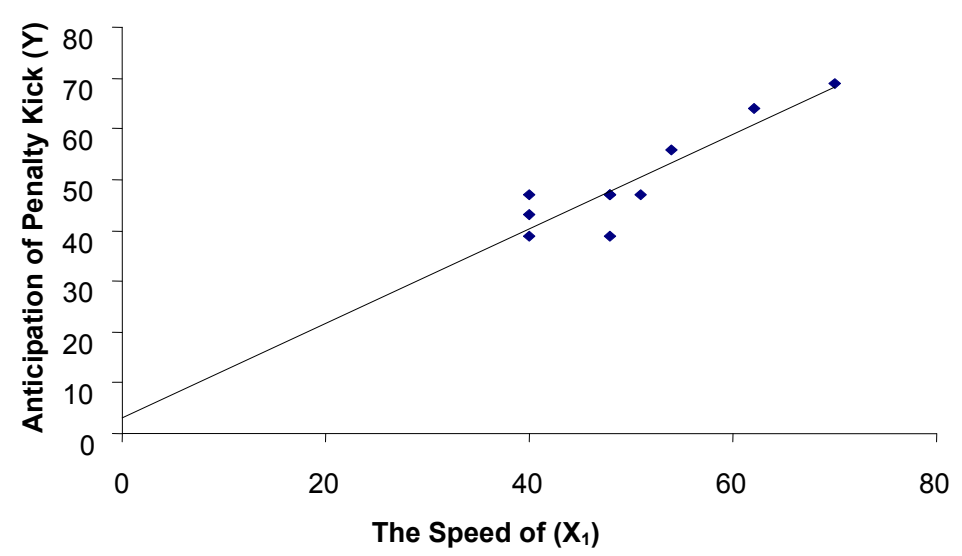

Figure 7. Regression equation for $\hat{\mathrm{Y}}=3.13+0.93 \mathrm{X}_{1}$

The second analysis results in the coefficient of the regression direction of $b$ of 0.80 and a constant of 9.89 . Thus, it was obtained the relationship between Agility $\left(\mathrm{X}_{2}\right)$ with the Anticipation of the Penalty Kick $(\mathrm{Y})$ which is expressed by the regression equation of $\hat{Y}=9.89+0.80 \mathrm{X}_{2}$ as visually presented in Figure 8 . To be used for predictive purposes, this equation must satisfy the requirement of linearity and significance. 


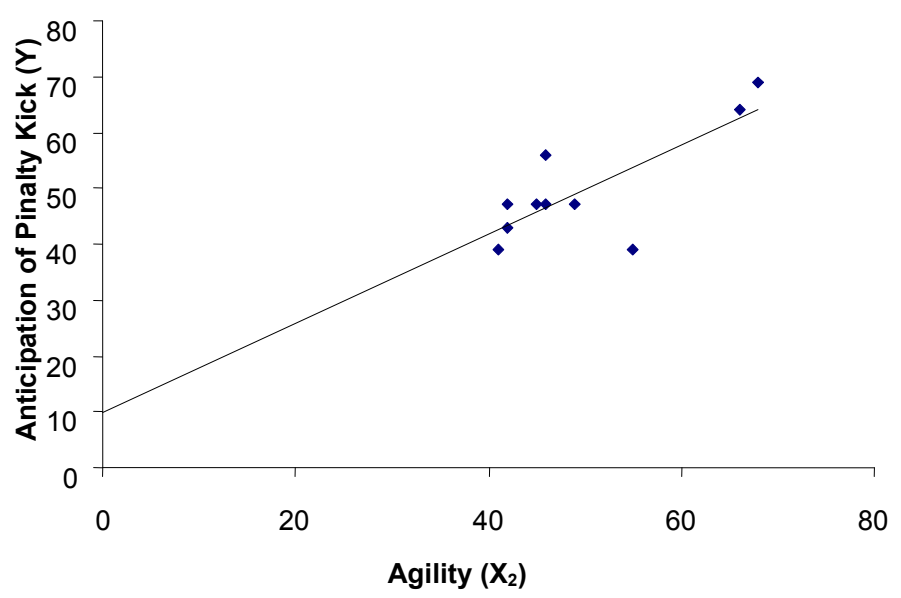

Figure 8. Regression equation for $\hat{\mathrm{Y}}=9.89+0.80 \mathrm{X}_{2}$

The degree of relationship between agility $\left(\mathrm{X}_{2}\right)$ and anticipation of penalty kick $\left(\mathrm{Y}_{2}\right)$ is shown by the correlation coefficient of $r_{y 2}=0.777$. The third analysis gave the coefficient of the regression direction of $b$ ias 0.81 and a constant of 9.17. Thus, it was obtained the relationship between Self-Confidence $\left(\mathrm{X}_{3}\right)$ with the Anticipation of the Penalty Kick $(\mathrm{Y})$ which is expressed by the regression equation of $\hat{Y}=9.17+0.81 \mathrm{X}_{3}$ as visually presented in Figure 9.

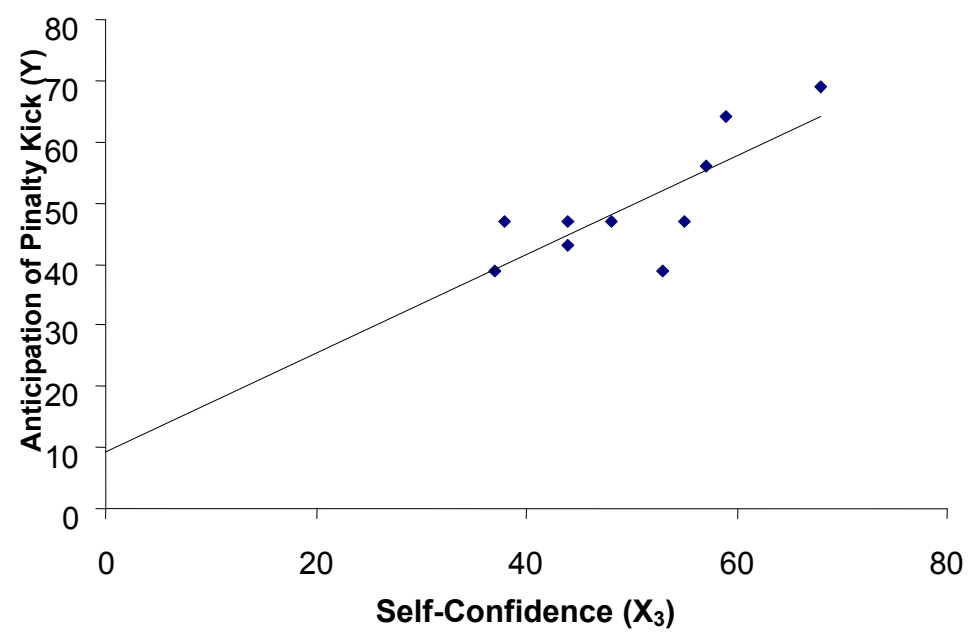

Figure 9. Regression equation for $\hat{Y}=9.17+0.81 X_{3}$

The degree of relationship between Self-Confidence $\left(\mathrm{X}_{3}\right)$ the Anticipation of the Penalty Kick $(\mathrm{Y})$ is shown by the correlation coefficient of $\mathrm{r}_{\mathrm{y} 3}=0.788$.

Results of multiple regression analysis between the Speed of Reaction $\left(\mathrm{X}_{1}\right)$, Agility $\left(\mathrm{X}_{2}\right)$ and Self-Confidence $\left(\mathrm{X}_{3}\right)$ with the Anticipation of the Penalty Kick (Y) are given $b_{1}=0.69 ; b_{2}=0.01$, and $b_{3}=0.39$ with a constant of $a=$ -4.88. Thus the relationship between the Speed of Reaction $\left(\mathrm{X}_{1}\right)$, Agility $\left(\mathrm{X}_{2}\right)$ Self-Confidence $\left(\mathrm{X}_{3}\right)$ with the Anticipation of the Penalty Kick $(\mathrm{Y})$ is shown in the regression equation of $\hat{\mathrm{Y}}=-4.88+0.69 \mathrm{X}_{1}+0.01 \mathrm{X}_{2}+$ $0.39 \mathrm{X}_{3}$. After calculating ANOVA to test the significance of regression, it is concluded that the model of the regression equation is highly significant. 
There is a positive relationship between the Speed of Reaction, Agility and Self-Confidence with the Anticipation of the Penalty Kick; meaning the higher the Speed of Reaction, the higher the Agility and more positive is the Self-Confidence; and the higher the Anticipation of the Penalty Kick. The proven the fourth hypothesis.

Data analysis showed that the correlation coefficient of $\mathrm{R}_{\mathrm{y} .123}=0.958$, and the coefficient of determination of $\mathrm{R}_{\mathrm{y} .123}^{2}=(0.958)^{2}=0.9178$ or $92 \%$. This means that a $92 \%$ change in the Anticipation of the Penalty Kick (Y) can be determined or explained by the Speed of Reaction, Agility and Self-Confidence together, and the remaining $8 \%$ is explained by other factors.

\section{Conclusion}

Based on the study it can be concluded that:

1) there is a relationship between the Speed of Reaction and the Anticipation of the Penalty Kick of soccer goalkeepers.

2) there is a relationship between Agility and the Anticipation of the Penalty Kick.

3) there is a relationship between positive Self-Confidence and the Anticipation of the Penalty Kick.

4) there is a relationship between the Speed of Reaction, Agility and Self-Confidence with the Anticipation of the Penalty Kick.

\section{Suggestion}

Some suggestions to improve the ability to anticipate a penalty kick are as follows:

1) To optimize the ability of the Anticipation of the Penalty Kick in addition to mastering the technique, goalkeepers should also have good Speed of Reaction, Agility and Self-Confidence.

2) For coaches, teachers and lecturers, they are expected to pay attention on factors that influence the Anticipation of the Penalty Kick.

\section{References}

Agus Sujanto Et All. (1982). Psikologi Kepribadian. Jakarta: Aksara Baru.

Bompa Tudor, O. (1999). Periodization training for sport. Auckland New Zealand: Human Kinetics.

Bouchard, C. (1978). Masalah-masalah Dalam Kedokteran Olahraga dan Coaching. Terjemahan Moh. Soebroto, Jakarta: Ditjen Depdikbud RI.

Coker, C. A. (2004). Motor Learning and Control for Practitioners. New York: McGraw-Hill.

Hawadi, R. A. (2001). Psikologi Perkembangan Anak, Mengenal Sifat. Bakat dan Kemampuan Anak. Jakarta: Grasindo.

Johnson, B. L., \& Nelson, J. K. (1979). Practical Measurements for Evaluation in Physical Education (3rd ed.). Minneapolis: Burgess Publishing Company.

Kirkendal, D. R., Gumber, J. J., \& Robert, E. J. E. (1980). Measurement and Evaluation for Physical Educators. Iowa: Wm. Chompany Publisher.

Kirkendall, D. R. (1988). Measurement and Evaluation for Physical Educators. Dubuque, IOWA, Wm., Brown Company.

Martens, R. (2004). Successful Coaching. Hong Kong: Human Kinetic.

National Institute for Sports. (1982). General Theory of Training. Lagos: Pan African Press Ltd.

Oxendine, J. B. (1984). Psychology of Motor Learning (2nd ed.). New Jersey: Prentice Hall - Inc.

Sage, G. H. (1977). Introduction to Motor Behaviour: A Neuropsyscological Approach (2nd ed.). Masachusetts: Addison Wesley Publishing Company.

Saleh, A. (1979). Tuntunan Sepakbola Untuk Anak Remaja. Jakarta: C.V Akadoma.

Satiadarma, M. P. (2000). Dasar-Dasar Psikologi Olahraga. Jakarta: Pustaka Sinar Harapan.

Schmidt, R. A. (1988). Motor control and learning a behavioral emphasis. Illinois: Human Kinetics Pub. Inc.

Sharkey Brain, J. (2003). Kebugaran dan Kesehatan (1st ed.). Jakarta: PT Raja Grafindo Persada.

Vealey, R. S. (n. d.). Sources of Sport-Confidence: Conceptuallization and Instrumen Development. Journal of Sport and Exercise Psychology, 25. 


\section{Copyrights}

Copyright for this article is retained by the author(s), with first publication rights granted to the journal.

This is an open-access article distributed under the terms and conditions of the Creative Commons Attribution license (http://creativecommons.org/licenses/by/3.0/). 